\title{
Determining ethyl methane sulfonate-mediated (EMS) mutagenesis protocol for inducing high biomass yield in fodder barley (Hordeum vulgare L.)
}

\author{
Fatuma Fora Sharamo*1, Hussein Shimelis², Boluwatife ModupeOluwa OlaOlorun ${ }^{2}$, Hezekiah Korir ${ }^{3}$, Annah \\ Hoka Indetie ${ }^{1}$ and Jacob Mashilo ${ }^{2}$
}

\author{
${ }^{1}$ Beef Research Institute-Lanet, Kenya Agricultural and Livestock Research Organization, Kenya \\ ${ }^{2}$ School of Agricultural, Earth and Environmental Sciences, African Centre for Crop Improvement, \\ University of KwaZulu-Natal, Pietermaritzburg, South Africa \\ ${ }^{3}$ Crops, Horticulture and Soils Department, Egerton University, Kenya
}

\author{
*Corresponding author: fashafo@gmail.com
}

\begin{abstract}
Barley (Hordeum vulgare L.) has narrow genetic base for selection of promising ideotypes for the following traits: high biomass yield for livestock feed, enhanced agronomic and nutritional traits, and resistance to biotic and abiotic stresses. Ethyl methane sulfonate (EMS) mutagenesis offers opportunities for inducing genetic variation for key traits for development of feed barley ideotypes. The objective of this study was to determine optimal EMS dosage and exposure time to induce genetic variation for selection of high biomass yield six-row feed barley mutants. Five EMS dosages (i.e. $0.1 \%, 0.3 \%, 0.5 \%, 0.7 \%$ and $0.9 \% \mathrm{v} / \mathrm{v}$ ) and five exposure times (i.e. $0.5 \mathrm{hr}, 1 \mathrm{hr}, 1.5 \mathrm{hr}, 2 \mathrm{hrs}$ and $2.5 \mathrm{hrs}$ ) were used on a six-row fodder barley using a $5 \times 5$ factorial treatment structure in a complete randomized design with three replications. Non-treated seed were used as a comparative control. Data was recorded for percent germination, seedling survival, shoot height, root height, shoot and root biomass. Significant $(p<0.05)$ EMS dosage $x$ exposure time was observed for assessed traits indicating their influence on phenotypic variation in feed barley. Overall, a declining trend was observed for assessed traits with increased EMS dosage and exposure time. The $\mathrm{LD}_{50}$ value of $0.64 \%$ ( $\mathrm{v} / \mathrm{v}$ ) EMS dosage was identified as an optimal dose for large-scale mutagenesis protocol to select fodder barley mutants with high biomass yield.
\end{abstract}

Keywords: Chemical mutagenesis, EMS, feed barley, lethal dose, optimal dose.

Abbreviations: EMS_Ethyl methane sulfonate; $\mathrm{LD}_{50}$ 50\% lethal dosage; DMSO_dimethyl sulfoxide; \%G_Percent germination; \%SS_ Percent seedling survival; SVI_Seedling vigor index; RB_Root biomass; SB_Shoot biomass; SL_Shoot length; RL_Root length.

\section{Introduction}

Barley (Hordeum vulgare L., $2 \mathrm{n}=2 \mathrm{x}=14$ ) is an important crop serving as human food and livestock feed (Giraldo et al., 2019). Six-row barley has higher protein content ( $13 \%)$, starch $(60 \%)$, fat (1.9\%) and high fiber (5\%); whereas two-row barley has a higher sugar content (68\%) suitable for the malting induatry (Gupta et al., 2010). Barely grain provides essential vitamins (i.e., $\mathrm{E}$ and $\mathrm{B}$-complex), minerals (i.e. $\mathrm{Ca}, \mathrm{P}, \mathrm{K}, \mathrm{Mg}$ and $\mathrm{Na}$ ), antioxidants and phytochemicals that provide excellent nutrition and health benefits (Baik and Ullrich, 2008; Sullivan et al., 2013).

Six-rowed barley has a narrow genetic base due to its inherent self-pollinating nature (Martin et al.,1991; Rasmusson and Phillips, 1997; Matus and Hayes, 2002). This has resulted in limited genetic variation for selection of promising ideotypes for high biomass yield for livestock feed, enhanced agronomic and nutritional traits, and resistance to biotic and abiotic stresses. (Muñoz-Amatriaín et al., 2014; Nice et al., 2017; Gao et al.,
2018). Therefore, there is need to widen the genetic base of barley to improve key agronomic traits including biomass and grain yield and component traits, nutritional composition, biotic and abiotic stress resistance.

Global barley production is estimated at 138 million tonnes from approximately 80 million hectares of land (FAOSTAT, 2019). European countries produce approximately $60 \%$ of the world's barley, whereas Asia and the Americas produce 15 and $13 \%$, respectively. Sub-Saharan African countries produce $~ 2.6$ million tonnes of barley. For instance, in Kenya, the estimated barley production is 50000 tonnes and contribute to $0.1 \%$ of the global production (FAOSTAT, 2019). Low barely production in sub-Saharan Africa (SSA) including Kenya is partly attributed to limited efforts to develop feed barley varieties that suits to the changing agro-climatic conditions. The Beef Research Institute (BRI) of the Kenya Agricultural and Livestock Research Organization (KALRO) focuses on improving productivity of beef 
cattle by generating appropriate, sustainable pasture and fodder management technologies through innovative research to support livestock production. Therefore, there is need to develop "climate smart" feed barley varieties with high biomass and grain yield to increase livestock feed production and curb the acute shortage of livestock feed (Lukuyu et al., 2011).

Mutation breeding using chemical mutagenesis is widely used procedure in improvement programs to create genetic variation and select "new" mutants possessing suitable agronomic, food and feed related nutritional traits (Krishna et al., 2016; Monica and Seetharaman, 2016). Ethyl methanesulfonate (EMS) is the most effective chemical mutagen commonly used for inducing genetic variation for quantitative and qualitative traits in crop plants (Ke et al., 2019; Devi and Mullainathan, 2012; Aruldoss et al., 2015). EMS alters the DNA structure directly by alkylating guanine (G) bases, causing mispairing with thiamine $(T)$ instead of cytosine (C), resulting in a transition from $G / C$ to $A / T$ (Rafi et al., 2016). The ease of application to seeds and its detoxification through hydrolysis for disposal makes EMS a recommendable mutagen for improving genetic diversity in crops (Pathirana, 2011; Serrat et al., 2014). In addition, EMS increase point mutations compared to physical mutagens such as gamma radiation (Van Harten, 1998). The most important step for inducing mutations is selection of an appropriate dosage of the mutagen; defined as the concentration of mutagen together with duration of treatment at a specific temperature.

Determining the $50 \%$ lethal dosage $\left(\mathrm{LD}_{50}\right)$ is an important step for initiating EMS mutagenesis (Jain, 2010). $\mathrm{LD}_{50}$ refers to the mutation dose that result in $50 \%$ reduction in seed germination percentage after seed exposure for a prescribed time period under specific conditions (Mba et al., 2010; Beyaz et al., 2016). In barley, EMS mutagenesis has been previously used to improve genetic variation and develop mutants possessing key agronomic traits such as grain yield; tolerance to abiotic and biotic stresses (Munns et al., 2010). The use of EMS to develop barely mutants with increased biomass yield in six-row fodder barley has not been reported in SSA. Therefore, it is important to induce mutation in fodder barley and select mutants with increased biomass yield for use in livestock production systems to improve livestock productivity. In light of the above background, the objective of this study was to determine optimal EMS dosage and exposure time to induce genetic variation in six-row fodder barley to select novel mutants.

\section{Results}

\section{Effect of EMS dosage, exposure time and their interaction} effects on assessed traits

Analysis of variance showing mean square values and test of significance for EMS dosage, exposure time and their interaction effects on germination percentage and growth parameters is shown in Table 1. EMS dosage $x$ exposure time interaction effect was highly significant $(p<0.001)$ for all recorded traits indicating that these two factors influenced phenotypic variation of feed barley. EMS dosage showed significant $(p \leq 0.01)$ effect on all assessed traits. The duration of exposure time to EMS showed significant $(p \leq 0.01)$ effect on $\mathrm{SL}, \mathrm{RL}, \mathrm{SB}$ and RB.

\section{Interactive effect of EMS dose and exposure time on assessed traits}

EMS dosage $x$ exposure time interaction effects on germination parameters of feed barley are presented in Table 2. \%G decreased with increased EMS dosage and exposure time. EMS dosage of $0.9 \% \mathrm{v} / \mathrm{v}$ for $2.5 \mathrm{hrs}$ recorded significantly low $\% \mathrm{G}$ of $23.4 \%$ whereas $0.1 \%$ v/v EMS for $1 \mathrm{hr}$ improved $\% \mathrm{G}$ by $71.3 \%$. Untreated seeds (control) recorded the highest \%G of $88.6 \%$. The \%SS also decreased with increased EMS concentration and exposure times. EMS dosage of $0.1 \% \mathrm{v} / \mathrm{v}$ for $2 \mathrm{hrs}$ recorded the highest \%SS of $76.2 \%$, whereas EMS dosage of $0.9 \% \mathrm{v} / \mathrm{v}$ for $2.5 \mathrm{hrs}$ resulted in the lowest \%SS of $14.3 \%$. The control treatment recorded \%SS of $90.5 \%$. Seedling vigor index (SVI) also decreased with increased EMS concentration and exposure times. Seed exposure for $1 \mathrm{hr}$ at EMS dosage of $0.1 \% \mathrm{v} / \mathrm{v}$ led to significantly higher SVI of 3814.4, whereas significantly lower SVI (906.5) was recorded for seeds exposed for $2 \mathrm{hrs}$ at $0.9 \% \mathrm{v} / \mathrm{v}$ EMS dosage.

EMS dosage $x$ exposure time interaction effects on growth parameters of feed barley are presented in Table 3. EMS concentration of $0.1 \% \mathrm{v} / \mathrm{v}$ for exposure time of $1.5 \mathrm{hrs}$ resulted in $S L$ of $42.8 \mathrm{~cm}$, whereas the lowest $S L$ of $25 \mathrm{~cm}$ was recorded at $0.9 \% \mathrm{v} / \mathrm{v}$ at exposure time of $1 \mathrm{hr}$. RL decreased as the concentration of EMS and exposure times increased. The highest RL of $22.5 \mathrm{~cm}$ was recorded at the lowest EMS dosage of $0.1 \% \mathrm{v} / \mathrm{v}$ for an exposure time of $2 \mathrm{hrs}$. Contrastingly, the lowest $\mathrm{RL}$ of $10 \mathrm{~cm}$ was recorded at the highest EMS dosage of $0.9 \% \mathrm{v} / \mathrm{v}$ and longest exposure time of $2.5 \mathrm{hrs}$. Shoot and root biomass decreased as the concentration of EMS and exposure times increased. The highest SB of $1.27 \mathrm{~g}$ was recorded for EMS dosage of $0.3 \% \mathrm{v} / \mathrm{v}$ for exposure time of $1 \mathrm{hr}$, whereas EMS dosage of $0.9 \% \mathrm{v} / \mathrm{v}$ for the longest exposure time of $2.5 \mathrm{hrs}$ led to the lowest SB of $0.36 \mathrm{~g}$. Exposing the seeds for the shortest time of $0.5 \mathrm{hrs}$ at the lowest EMS dosage of $0.1 \% \mathrm{v} / \mathrm{v}$ led to seedlings with the highest RB $(0.68 \mathrm{~g})$. The lowest RB $(0.17 \mathrm{~g})$ was recorded for seeds treated with $0.9 \% \mathrm{v} / \mathrm{v}$ EMS dosage for a period of $2 \mathrm{hrs}$.

\section{Determination of $L D_{50}$}

A fitted model for \%G and EMS dosage was used to calculate $L D_{50}$ using the linear regression equation of $y=-56.02 x+85.81$ (Figure 1). Generally, increased EMS dosage resulted in reduced \%G. According to the fitted model, $L D_{50}$ value of $0.64 \%(\mathrm{v} / \mathrm{v})$ EMS dosage was the ideal for inducing mutation in fodder barley.

\section{Discussion}

Genetic improvement of barley for agronomic and food- and fodder-related nutritional traits, and resistance to biotic and abiotic stress factors is limited due to the low genetic base of the crop. As a result, development and release of "new" barley varieties for the food and feed industry has been limited in subSaharan Africa including Kenya. Thus, increasing genetic diversity in barley is useful for developing fodder barley varieties with enhanced biomass yield and key farmer-preferred traits for cultivation and industrial uses. The present study determined an effective EMS protocol for inducing genetic variation for high biomass yield of six-row fodder barley. The study revealed that increased EMS dosage resulted in decreased 
Table 1. Analysis of variance showing mean squares and significance tests for EMS dosage, exposure time and their interaction effects for assessed traits in six-row fodder barley.

\begin{tabular}{|l|c|c|c|c|c|c|c|c|}
\hline Source of variation & df & SL & RL & SB & RB & $\%$ G & $\%$ SS & SVI \\
\hline Replicates & 2 & 5.27 & 13.04 & 0.04 & 0.05 & 15.10 & 143.94 & 44162.69 \\
\hline Dosage (D) & 4 & $277.01^{* *}$ & $132.80^{* *}$ & $0.82^{* *}$ & $0.09^{* *}$ & $2006.53^{* *}$ & $1161.79^{* *}$ & $9800264.92^{* *}$ \\
\hline Exposure time (ET) & 4 & $88.94^{* *}$ & $6.99^{*}$ & $0.22^{* *}$ & $0.08^{* *}$ & $46.48^{\text {ns }}$ & $76.98^{\text {ns }}$ & $350591.43^{\text {ns }}$ \\
\hline D x ET & 16 & $33.60^{* *}$ & $15.68^{* *}$ & $0.07^{* *}$ & $0.03^{*}$ & $168.15^{*}$ & $430.51^{*}$ & $572030.85^{* *}$ \\
\hline Error & 48 & 1.43 & 1.66 & 0.02 & 0.01 & 53.37 & 167.58 & 517688.65 \\
\hline
\end{tabular}

$\mathrm{df}=$ degrees of freedom, $\mathrm{SL}=$ Shoot length, $\mathrm{RL}=$ Root length, $\mathrm{SB}=$ Shoot biomass, $\mathrm{RB}=$ Root biomass, $\% \mathrm{G}=$ Germination percent, \%SS $=$ Seedling survival percent, $\mathrm{SVI}=\mathrm{Seedling}$ vigor index,${ }^{*}=$ significant at $5 \%$ level of significance, ${ }^{* *}=$ significant at $1 \%$ level of significance, $n s=$ non-significance.

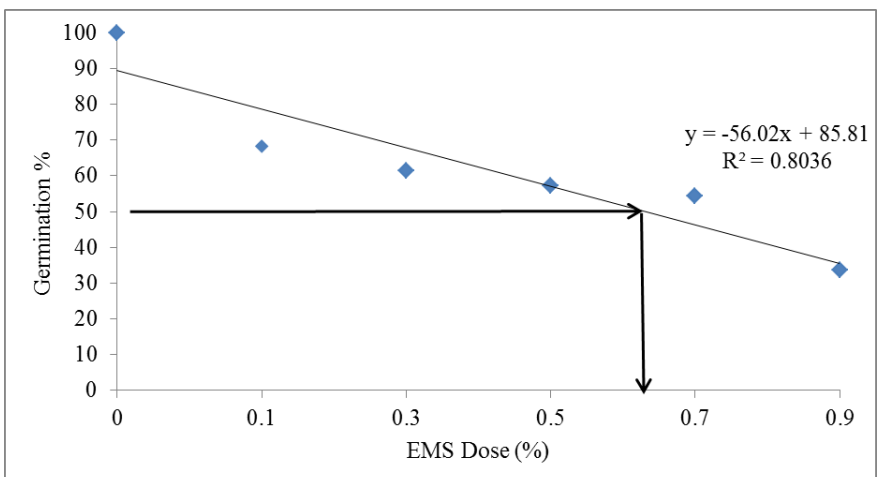

Fig 1. Germination percentage plotted against EMS dosage and used to calculate the lethal dose $\left(\mathrm{LD}_{50}\right)$ for inducing random mutations in a six-row fodder barley.

Table 2. Mean \pm standard error for percentage germination (\%G), percent survival (\%SS) and seedling vigor index (SVI) of fodder barley assessed under variable EMS dosage and exposure time.

\begin{tabular}{|c|c|c|c|c|}
\hline EMS dosage (\%) & $\begin{array}{l}\text { Exposure time } \\
\text { (hr) }\end{array}$ & $\% \mathrm{G}$ & $\%$ SS & SVI \\
\hline \multirow[t]{5}{*}{0.1} & 0.5 & $53.4 \pm 3.70$ bcdefg & $66.4 \pm 5.03 b$ & $2751.9 \pm 171.02$ bcdefg \\
\hline & 1 & $71.3 \pm 7.50 \mathrm{~b}$ & $67.9 \pm 8.94 b$ & $3814.4 \pm 362.90 \mathrm{~b}$ \\
\hline & 1.5 & $67.8 \pm 3.63 b c$ & $71.4 \pm 0.00 b$ & $3667.7 \pm 154.65 b c$ \\
\hline & 2 & $61.9 \pm 4.77 \mathrm{bcd}$ & $76.2 \pm 4.77 b$ & $3468.5 \pm 309.58 \mathrm{bcd}$ \\
\hline & 2.5 & $48.2 \pm 4.47 \mathrm{bcdefg}$ & $57.1 \pm 8.23 b$ & $2903.8 \pm 209.47 \mathrm{bcdef}$ \\
\hline \multirow[t]{5}{*}{0.3} & 0.5 & $52.4 \pm 4.73 b c d e f g$ & $54.0 \pm 3.09 b c$ & $3134.5 \pm 323.04$ bcde \\
\hline & 1 & $48.2 \pm 4.47 \mathrm{bcdefg}$ & $52.4 \pm 4.73 b c$ & $2451.3 \pm 301.30 \mathrm{cdefgh}$ \\
\hline & 1.5 & $62.4 \pm 4.51 \mathrm{bcd}$ & $52.4 \pm 4.73 b c$ & $3094.8 \pm 245.51$ bcde \\
\hline & 2 & $52.4 \pm 4.73 b c d e f g$ & $59.5 \pm 1.48 b$ & $2869.2 \pm 287.95 b c d e f$ \\
\hline & 2.5 & $56.6 \pm 0.50$ bcdef & $74.8 \pm 2.50 \mathrm{~b}$ & $3078.4 \pm 21.43 \mathrm{bcde}$ \\
\hline \multirow[t]{5}{*}{0.5} & 0.5 & $42.9 \pm 0.00$ defgh & $67.3 \pm 5.15 b$ & $2420.6 \pm 40.02$ defgh \\
\hline & 1 & $56.0 \pm 6.73$ bcdef & $55.7 \pm 6.78 b c$ & $3176.8 \pm 402.05 \mathrm{bcde}$ \\
\hline & 1.5 & $46.1 \pm 3.17$ cdefgh & $47.1 \pm 9.26 b c$ & $2753.4 \pm 212.07 b d c e f g$ \\
\hline & 2 & $40.8 \pm 6.11$ defgh & $51.9 \pm 4.50 b c$ & 1802.9 $\pm 260.09 f g h i j$ \\
\hline & 2.5 & $55.0 \pm 1.03 b c d e f g$ & $51.9 \pm 4.50 b c$ & $3008.3 \pm 165.69 \mathrm{bcdef}$ \\
\hline \multirow[t]{5}{*}{0.7} & 0.5 & $57.6 \pm 0.50 \mathrm{bcde}$ & $51.9 \pm 4.50 b c$ & $3301.6 \pm 106.16$ bcde \\
\hline & 1 & $46.6 \pm 3.73$ cdefgh & $59.5 \pm 2.40 b$ & $2585.8 \pm 207.01 \mathrm{cdefgh}$ \\
\hline & 1.5 & $51.3 \pm 4.32 b c d e f g$ & $59.5 \pm 2.40 b$ & $2500.6 \pm 225.81$ cdefgh \\
\hline & 2 & $55.0 \pm 1.04$ bcdef & $57.1 \pm 8.23 b$ & 2278.2 \pm 74.01 defghi \\
\hline & 2.5 & $42.8 \pm 0.01$ defgh & $49.1 \pm 3.35 b c$ & $2203.0 \pm 33.16 \mathrm{efghi}$ \\
\hline \multirow[t]{5}{*}{0.9} & 0.5 & $36.4 \pm 4.18$ efgh & $57.1 \pm 14.27 b$ & 1578.8 $\pm 144.10 \mathrm{ghij}$ \\
\hline & 1 & $33.4 \pm 4.77 f g h$ & $56.7 \pm 14.07 b$ & $1078.1 \pm 112.04 \mathrm{ij}$ \\
\hline & 1.5 & $31.3 \pm 2.70 \mathrm{gh}$ & $52.4 \pm 9.50 b c$ & $925.4 \pm 181.65 j$ \\
\hline & 2 & $23.8 \pm 4.77 \mathrm{~h}$ & $37.7 \pm 18.84 b c$ & $906.5 \pm 170.36 \mathrm{j}$ \\
\hline & 2.5 & $23.4 \pm 4.73 \mathrm{~h}$ & $14.3 \pm 0.00 c$ & 1418.7 $\pm 155.16 \mathrm{hij}$ \\
\hline Control & & $88.6 a$ & $90.5 a$ & $4284.7 a$ \\
\hline
\end{tabular}


Table 3. Mean \pm standard error for shoot and root traits of fodder barley assessed under varied EMS dosage and exposure time.

\begin{tabular}{|c|c|c|c|c|c|}
\hline $\begin{array}{l}\text { EMS } \\
\text { dosage (\%) }\end{array}$ & $\begin{array}{l}\text { Exposure } \\
\text { time (hr) }\end{array}$ & $\mathrm{SL}(\mathrm{cm})$ & $\mathrm{RL}(\mathrm{cm})$ & SB (g) & RB (g) \\
\hline \multirow[t]{5}{*}{0.1} & 0.5 & $34.7 \pm 0.30 \mathrm{ef}$ & $16.9 \pm 0.63 \mathrm{defg}$ & $1.13 \pm 0.07 \mathrm{abcd}$ & $0.68 \pm 0.09 a$ \\
\hline & 1 & $35.1 \pm 0.26 \mathrm{ef}$ & $18.6 \pm 0.94 \mathrm{bcde}$ & $1.11 \pm 0.04 \mathrm{abcd}$ & $0.46 \pm 0.04 a b c$ \\
\hline & 1.5 & $33.4 \pm 1.12 \mathrm{fg}$ & $20.8 \pm 0.53 a b c$ & $0.93 \pm 0.05 \mathrm{abcde}$ & $0.39 \pm 0.01 \mathrm{abc}$ \\
\hline & 2 & $33.5 \pm 0.77 \mathrm{fg}$ & $22.5 \pm 0.33 a$ & $0.74 \pm 0.06$ defghi & $0.25 \pm 0.06 b c$ \\
\hline & 2.5 & $38.1 \pm 0.34$ cde & $22.4 \pm 1.97 a$ & $0.76 \pm 0.13$ cdefghi & $0.33 \pm 0.04 a b c$ \\
\hline \multirow[t]{5}{*}{0.3} & 0.5 & $38.0 \pm 0.26 \mathrm{cde}$ & $21.7 \pm 1.06 a b$ & $0.93 \pm 0.04$ abcde & $0.44 \pm 0.11 \mathrm{abc}$ \\
\hline & 1 & $33.0 \pm 1.38 \mathrm{fgh}$ & $17.7 \pm 0.89 \mathrm{cdef}$ & $1.27 \pm 0.03 a$ & $0.59 \pm 0.11 \mathrm{ab}$ \\
\hline & 1.5 & $35.4 \pm 0.30 \mathrm{def}$ & $14.1 \pm 0.84 \mathrm{fgh}$ & $1.18 \pm 0.01 \mathrm{abc}$ & $0.46 \pm 0.11 \mathrm{abc}$ \\
\hline & 2 & $37.3 \pm 1.04 \mathrm{cde}$ & $17.5 \pm 0.76 \mathrm{cdef}$ & $0.90 \pm 0.05 a b c d e f$ & $0.28 \pm 0.01 b c$ \\
\hline & 2.5 & $39.6 \pm 0.42 a b c$ & $14.8 \pm 0.54$ & $0.83 \pm 0.04 \mathrm{bcdefgh}$ & $0.25 \pm 0.07 b c$ \\
\hline \multirow[t]{5}{*}{0.5} & 0.5 & $42.7 \pm 0.43 a b$ & $13.8 \pm 0.76 \mathrm{ghi}$ & $1.22 \pm 0.05 \mathrm{ab}$ & $0.30 \pm 0.04 b c$ \\
\hline & 1 & $40.9 \pm 0.30 \mathrm{abc}$ & $15.8 \pm 1.25 \mathrm{efgh}$ & $1.03 \pm 0.26 \mathrm{abcd}$ & $0.32 \pm 0.07 b c$ \\
\hline & 1.5 & $42.8 \pm 0.33 a$ & $17.7 \pm 0.24 \mathrm{cdef}$ & $0.68 \pm 0.14$ efghi & $0.36 \pm 0.10 \mathrm{abc}$ \\
\hline & 2 & $30.1 \pm 0.89 \mathrm{ghi}$ & $14.3 \pm 0.47 \mathrm{fgh}$ & $0.88 \pm 0.07 \mathrm{abcdefg}$ & $0.30 \pm 0.08 b c$ \\
\hline & 2.5 & $37.8 \pm 1.41 \mathrm{cde}$ & $16.8 \pm 0.66 \mathrm{defg}$ & $1.21 \pm 0.04 a b$ & $0.27 \pm 0.07 b c$ \\
\hline \multirow[t]{5}{*}{0.7} & 0.5 & $42.7 \pm 0.74 a b$ & $14.7 \pm 0.67 \mathrm{fgh}$ & $1.00 \pm 0.13 \mathrm{abcd}$ & $0.25 \pm 0.04 b c$ \\
\hline & 1 & $39.0 \pm 0.58 \mathrm{bcd}$ & $16.4 \pm 0.57$ efg & $0.96 \pm 0.11 \mathrm{abcde}$ & $0.38 \pm 0.05 b c$ \\
\hline & 1.5 & $34.9 \pm 0.62 \mathrm{ef}$ & $13.7 \pm 0.45 \mathrm{ghi}$ & $0.74 \pm 0.01$ defghi & $0.33 \pm 0.02 a b c$ \\
\hline & 2 & $27.6 \pm 0.23 i j k$ & $13.8 \pm 0.71 \mathrm{ghi}$ & $0.46 \pm 0.04 \mathrm{ghi}$ & $0.27 \pm 0.01 b c$ \\
\hline & 2.5 & $34.6 \pm 0.67 \mathrm{ef}$ & $16.9 \pm 0.28 \mathrm{defg}$ & $0.90 \pm 0.05 a b c d e f$ & $0.22 \pm 0.03 c$ \\
\hline \multirow[t]{5}{*}{0.9} & 0.5 & $29.8 \pm 0.62 \mathrm{hij}$ & $14.5 \pm 0.90 f g h$ & $0.57 \pm 0.05 f g h i$ & $0.21 \pm 0.10 c$ \\
\hline & 1 & $25.0 \pm 0.97 \mathrm{k}$ & $10.0 \pm 0.00 \mathrm{j}$ & $0.50 \pm 0.00 f g h i$ & $0.32 \pm 0.05 b c$ \\
\hline & 1.5 & $28.4 \pm 0.72 i j k$ & $10.5 \pm 1.20 \mathrm{ij}$ & $0.46 \pm 0.04 \mathrm{ghi}$ & $0.28 \pm 0.10 b c$ \\
\hline & 2 & $26.1 \pm 0.08 \mathrm{jk}$ & $12.3 \pm 1.13 \mathrm{hij}$ & $0.44 \pm 0.06 h i$ & $0.17 \pm 0.10 c$ \\
\hline & 2.5 & $28.8 \pm 1.40 \mathrm{ij}$ & $14.1 \pm 0.09 \mathrm{fgh}$ & $0.36 \pm 0.07 i$ & $0.27 \pm 0.06 b c$ \\
\hline Control & & $40.3 a b c$ & $20.8 \mathrm{abc}$ & 1.10abcd & $0.42 \mathrm{bc}$ \\
\hline
\end{tabular}

germination percentage, seedling survival, seedling height, root and shoot biomass (Table 2). A reduced germination percentage could be attributed to disturbances of seed meristematic tissue at cellular level resulting in chromosome damage, disrupting growth promoters due to increased accumulation of growth inhibitors (Jayakumar and Selvaraj, 2003). In rice, EMS treatment significantly decreased germination percentage (Talebi et al., 2012), concurring with the present findings. Earlier studies carried out in barley reported a decrease in germination due to changes in metabolic functioning of cells after EMS treatment (Sharma and Swaminathan, 1969). Hadebe et al. (2017) reported that the highest reduction in germination (10\%) was observed in vernonia seeds treated at high EMS dose of $1.1 \%$ and long exposure duration of $2 \mathrm{hr}$, which is in agreement with the present study. A study by Espina et al. (2018) in soybean showed that the highest EMS dosage of $0.9 \% \mathrm{v} / \mathrm{v}$ for longest exposure duration of $24 \mathrm{hrs}$, resulted in $0 \%$ germination, while $70 \%$ germination capacity was obtained at the lowest EMS dose of $0.3 \%$ at shortest exposure duration used, in agreement with the result of the present study (12hrs). Generally, EMS dosage of $0.9 \% \mathrm{v} / \mathrm{v}$ and exposure time of $2.5 \mathrm{hrs}$ appears effective for inducing genetic variation of the resultant mutant plants. This value is lower than the value reported in the previous studies and could be due to differences in crop species. The highest dose obtained in the present study could be the best dose to induce high mutation frequency in feed barley. The present study showed that increased exposure duration and EMS dose led to a decline in seedling survival (Table 2). For example, $0.1 \% \mathrm{v} / \mathrm{v}$ EMS dosage for $2 \mathrm{hrs}$ gave the highest survival rate of $76.2 \%$; whereas $0.9 \% \mathrm{v} / \mathrm{v}$ EMS dosage at $2.5 \mathrm{hrs}$ resulted in the lowest survival rate of $14.3 \%$. This could be because seeds exposed to shorter periods absorb lower quantities of the mutagen, leading to lesser detrimental effect as compared to those exposed for longer durations (Kulkarni, 2011). For example, a study by Shirani et al. (2016) showed that at high concentrations of EMS $(3 \% \mathrm{v} / \mathrm{v})$ and longer exposure duration of $3 \mathrm{hrs}$ resulted in no survival of banana shoot tips. A significant reduction in survival percentage $(42.84 \%)$ was observed at the highest EMS doses of $0.5 \%$ and exposure duration of $5 \mathrm{hrs}$ in Coriandrum sativum (Kumar and Pandey, 2019). Decrease in survival rate may be due to physiological disturbances, cytogenetic and chromosomal damage which lead to mitotic arrest and reduced cell division (Khursheed et al., 2008; Girija et al., 2013). This indicates optimum EMS dosage and exposure time determine survival rate of barely seedlings.

EMS is known to affect plant growth and development. In the present study, increased EMS dosage and exposure time caused a decline in shoot length, root length, shoot and root biomass (Table 3). This might be attributed to inactivation of auxin levels, which are plant-growth promoters (Kanakamanay, 2008; Ashok Kumar et al., 2009). Ali et al. (2019) reported a significant decrease in the root length of upland rice using EMS concentration of $2 \% \mathrm{v} / \mathrm{v}$, much higher than tested concentrations in the present study. Muñoz-Miranda et al. (2019) reported that moderate concentrations of EMS $(0.5 \%$ $\mathrm{v} / \mathrm{v}$ ) and longer exposure duration of $3 \mathrm{hrs}$ resulted in reduced 
plant growth. This implies that higher EMS dose and longer exposure duration to EMS caused decreased levels in the assessed growth parameters of barley.

The $\mathrm{LD}_{50}$ of the mutagen is useful for determining an optimal dose for mutation induction. The $\mathrm{LD}_{50}$ was calculated using seed germination percentage at different doses of EMS (Figure 1). As a result, EMS dosage of $0.64 \% \mathrm{v} / \mathrm{v}$ was recommended as the most effective and efficient for inducing genetic variability and selection of promising six-row barley mutants. The $\mathrm{LD}_{50}$ in the present study is much lower than a value of $1.2 \%$ reported in banana (Shirani et al., 2016). Olaolorun et al. (2019) reported lethal doses of $1.07 \%$ and $1.81 \% \mathrm{v} / \mathrm{v}$ EMS for wheat genotypes LM29 and LM75, respectively. These values are much higher than reported in the present study attributed to differences in crop species, genotypes used and ambient conditions during mutagenesis (Liamngee et al., 2017). For artificially induced mutations either with physical or chemical mutagens, $L D_{50}$ is considered to be an ideal level to achieving high frequency of mutations (Anbarasan et al., 2013). The present study determined the optimum treatment condition of $0.64 \% \mathrm{v} / \mathrm{v}$ EMS concentration. The mutagenesis protocol will be useful to develop recessive and point mutations to aid selection of best individuals involving the M2-M5 mutant families with high fodder biomass yield.

\section{Materials and Methods}

\section{Experimental site and plant materials}

The study was conducted under glasshouse conditions at the Controlled Environmental Facility (CEF) of the University of KwaZulu-Natal, Pietermaritzburg, South Africa. A commonly used six-row feed barley landrace variety that is early maturing but less biomass was obtained from Kenya Agricultural and Livestock Research Organization (KALRO) Lanet and used for the study.

\section{Experimental design and treatments}

The experiment was conducted as a factorial $(5 \times 5)$ treatment structure involving five EMS dosages (i.e., $0.1 \%, 0.3 \%, 0.5 \%$, $0.7 \%$ and $0.9 \%$ ) and five levels of exposure periods (i.e. $0.5 \mathrm{hr}$, $1 \mathrm{hr}, 1.5 \mathrm{hr}, 2 \mathrm{hrs}$ and $2.5 \mathrm{hrs}$ ) using a factorial treatment structure in a completely randomized design (CRD) with three replications. EMS treated seeds were established in seedling trays under a constant temperature of $24^{\circ} \mathrm{C}$. Untreated seed were used as a comparative control.

\section{Seed sterilization and pre-soaking}

Seed sterilization and pre-soaking was done as described in Mba et al. (2010). Thirty uniform seeds were placed inside a customized $8 \mathrm{~cm}$ long and $4 \mathrm{~cm}$ wide labelled plastic mesh bags for each treatment combination. The seeds were surface sterilized by soaking the mesh bags in $70 \%$ ethanol for $1 \mathrm{~min}$ and washing under running water at room temperature for $2 \mathrm{~min}$. The seeds were then soaked in $30 \%$ sodium hypochlorite solution for $5 \mathrm{~min}$ and washed using running water for $2 \mathrm{~min}$. The seeds were then pre-soaked in distilled water for $24 \mathrm{hrs}$ at room temperature before EMS treatment. Untreated seed were soaked in distilled water for $24 \mathrm{hrs}$ at room temperature and then air-dried before planting alongside the EMS treated seeds.

\section{EMS preparation}

The EMS solution was prepared following protocol described by Mba et al. (2010). Briefly, a $2 \%$ solution of dimethyl sulfoxide (DMSO) was prepared prior to EMS preparation, for use as a carrier agent for EMS treatment. The DMSO was autoclaved at $120{ }^{\circ} \mathrm{C}$ and $103.5 \mathrm{kPa}$ for $15 \mathrm{~min}$ and set to cool down at room temperature for 5-6 hrs. The EMS solutions at five concentration levels of $0.1,0.3,0.5,0.7$ and $0.9 \%$ were prepared accordingly by making up $1 \mathrm{~L}$ with $2 \%$ DMSO solution using a micropipette.

\section{EMS mutagenesis}

Seeds were subjected to five EMS dosages $(0.1,0.3,0.5,0.7$ and $0.9 \% \mathrm{v} / \mathrm{v}$ ) at constant temperature of $24^{\circ} \mathrm{C}$ for five exposure periods $(0.5 \mathrm{hr}, 1 \mathrm{hr}, 1.5 \mathrm{hrs}, 2 \mathrm{hrs}$ and $2.5 \mathrm{hrs})$. The mesh bags containing the seeds were immersed in EMS solution in a beaker. The beakers were placed in a water bath maintained at $24^{\circ} \mathrm{C}$ for the different time durations. After each treatment condition, excess EMS was washed off using running water for $3 \mathrm{hrs}$. The mesh bags were placed on paper towels afterwards overnight to drain the excess EMS solution. The seeds were planted the following morning as described below.

\section{Trial establishment}

EMS-treated and untreated seeds (comparative control) were planted at $1 \mathrm{~cm}$ depth in seedling trays under glasshouse condition using pine bark growth medium and one seed was planted per hole. The seedlings were watered four times daily using a mist irrigation system. The relative humidity in the glasshouse was set at $\sim 63 \%$ and controlled using a fogger system.

\section{Data collection}

Data were collected on the following parameters: percent germination $(\% \mathrm{G})$ recorded as the proportion of germinated seeds per total number of seeds sown at eight days after sowing. Seedling survival (\%SS) was calculated as the proportion of number of survived seedlings per total number of germinated seeds. Destructive sampling was done 21 days after planting and data on shoot height, root height, shoot biomass and root biomass was collected. Shoot length (SL, in $\mathrm{cm}$ ) was measured as the length from the base of the plant to the tip of the flag leaf, whereas root length ( $R L$, in $\mathrm{cm}$ ) was measured from the base of the plant to the tip of the longest root. Seedling vigour index (SVI) was estimated using a formula described by AbdulBaki and Anderson (1973) as follows:

SVI $=$ Germination $(\%) \times$ Total seedling length $(\mathrm{cm})$

\section{Data analyses}

Data collected was subjected to analysis of variance (ANOVA) using PROC GLM procedure of the SAS package version 9.3. Treatment means were separated using Tukey's test procedure at $5 \%$ level of significance. The lethal dose $\left(L_{50}\right)$ was estimated using a linear regression model as follows: $y=a+b x$ where $y$ is the dependent variable (i.e., germination percentage), $x$ is the independent variable (EMS dosage), and $a$ and $b$ are the constant and slope, respectively. 


\section{Conclusions}

The treatment combinations that yielded optimum treatment conditions in this study will be utilized to induce large-scale mutation in barley to select novel mutants varieties. The present study determined the optimum treatment condition for inducing genetic variation in feed barley. Results revealed that EMS dosage of $0.64 \% \mathrm{v} / \mathrm{v}$ of EMS can be used to increase genetic variability for key traits in barley.

\section{Acknowledgements}

The authors gratefully acknowledge the support of International Atomic Energy Agency (IAEA) for funding the fellowship training, University of KwaZulu-Natal (UKZN) and Kenya Agricultural and Livestock Research Organization (KALRO) for facilitating the study.

\section{References}

Abdul-Baki A, Anderson JD (1973) Vigor determination in soybean seed by multiple criteria. Crop Sci. 13: 630-633.

Ali A, Nualsri C, Soonsuwon W (2019) Induced mutagenesis for creating variability in Thailand's upland rice (cv. Dawk Payawm and Dawk Kha 50) using ethyl methane sulphonate (EMS). Sarhad J Agric. 35(1): 293-301.

Anbarasan K, Sivalingam D, Rajendran R, Anbazhagan M, Chidambaram AIA (2013) Studies on the mutagenic effect of EMS on seed germination and seedling characters of Sesame (Sesamum indicum L.) Var.T MV3. Int J Res Biol Sci. 3: 68-70.

Aruldoss T, Mullainathan L, Natarajan S (2015) Effect of induced mutagenesis on quantitative characteristics of chilli (Capsicum annum (L). var- K1 in M2 generation. IAJMR. 1(3): 265- 272.

Ashok Kumar V, Kumari RU, Amutha R, Siva Kumar T, Juliet Hepziba S, Ananda Kumar C (2009) Effect of chemical mutagen on expression of characters in arid legume pulse-cowpea (Vigna unguiculata (L.) Walp.). Res J Agric Biol Sci. 5: 11151120.

Baik BK, Ullrich SE (2008) Barley for food: characteristics, improvement, and renewed interest. J Cereal Sci. 48 233-242.

Beyaz R, Sancak C, Yildiz Ç, Kuşvuran Ş, Yildiz M (2016) Physiological responses of the M1 sainfoin (Onobrychis viciifolia Scop.) plants to gamma radiation. Appl Radiat Isotopes. 118: 73-79.

Devi AS, Mullainathan L (2012) Genotoxicity effect of ethylmethanesulfonate on root tip cells of chilli (Capsicum annuum L.). World J Agric Res. 7 (4): 368-374.

Espina MJ, Ahmed CMS, Bernardini A, Adeleke E, Yadegari Z, Arelli P, Pantalone V, Taheri A (2018) Development and phenotypic screening of an ethylmethanesulfonate mutant population in soybean. Front Plant Sci. 9:394.

FAOSTAT (2019) Crops. http://www.fao.org/faostat/en/\#data/QC. Accessed $3^{\text {rd }}$ March, 2020.

Gao R, Guo G, Fang C, Huang S, Chen J, Lu, Liu C (2018) Rapid generation of barley mutant lines with high nitrogen uptake efficiency by microspore mutagenesis and field screening. Front Plant Sci. 9:450.
Giraldo P, Benavente E, Manzano-Agugliaro F, Gimenez E, (2019) Worldwide research trends on wheat and barley: $A$ bibliometric comparative analysis. Agron J. 9:352.

Girija M, Gnanamurthy S, Dhanavel D (2013) Genetic diversity analysis of cowpea mutant (Vigna unguiculata L.) Walp) as revealed by RAPD marker. Inter J Adv Res. 1:139-147.

Gupta M, Abu-Ghannam N, Gallagher E (2010) Barley for brewing: characteristic changes during malting, brewing and applications of its by-products. Compr Rev Food Sci Food Saf. 9(3): 318-328.

Hadebe ST, Modi AT, Shimelis HA (2017) Determination of optimum ethylmethanesulfonate conditions for chemical mutagenesis of selected vernonia (Centrapalus pauciflorus) accessions. S Afr J Plant Soil. 34 2: 311-317.

Jain SM (2010) Mutagenesis in crop improvement under the climate change. Rom Biotechnol Lett. 15: 88-106.

Jayakumar S, Selvaraj R (2003) Mutagenic effectiveness and efficiency of gamma rays and ethyl methane sulphonate in sunflower. Madras Agric J. 90: 574-576.

Kanakamanay, M (2008) Induction of genetic variability in kacholam, Kaempferia galanga L. Plant Mutat Rep. 2: 4-6.

Ke C, Guan W, Bu S, Li X, Deng Y, Wei Z, Wu W, Zheng Y (2019) Determination of absorption dose in chemical mutagenesis in plants. PLoS ONE. 14:e0210596

Khursheed T, Ansari MYK, Shahab D (2008) Studies on the effect of caffeine on seed germination, seedling survival and pollen fertility in Helianthus annuus L. Var Mod. Adv Plant Sci. 20: 311-312.

Krishna H, Alizadeh M, Singh D, Singh U, Chauhan N, Eftekhari M, Sadh RK (2016) Somaclonal variations and their applications in horticultural crops improvement. Biotech. 6: 54-71.

Kumar G, Pandey A (2019) Ethyl methane sulphonate induced changes in cyto-morphological and biochemical aspects of Coriandrum sativum L. J Saudi Soc Agric Sci. 18: 469-475.

Kulkarni GB (2011) Effect of mutagen on pollen fertility and other parameters in horsegram (Macrotyloma uniflorum (LAM.) VERDC). Biosci Discov. 2(1): 146-150.

Liamngee SM, Ogah JJ, Amagu KT, Kwon-Ndung EH, lorkor D, Tervershima JE (2017) Mutagenic action of sodium azide on germination and emergence in landraces of Phaseolus vulgaris L.on the Jos plateau agro-ecological zone. J Agric Vet Sci. 10 (2-1): 64-70.

Lukuyu B, Franzel S, Ongadi P, Duncan A (2011) Livestock feed resources: current production and management practices in central and northern rift valley provinces of Kenya. Livest Res Rural Dev. 23(5): 1-17.

Martin JM, Blake TK, Hockett EA (1991) Diversity among North American spring barley cultivars based on coefficients of parentages. Crop Sci. 31:1131-7.

Matus IA, Hayes PM (2002) Genetic diversity in three groups of barley germplasm assessed by simple sequence repeats. Genome. 45:1095-1106.

Mba C, Afza R, Bado S, Jain, SM (2010) Induced mutagenesis in plants using physical and chemical agents. In: Davey, M.R., Anthony, P. (eds) Plant cell culture: essential methods. Chichester: John Wiley \& Sons, Ltd. 111-130. 
Munns R, James RA, Sirault XRR, Furbank RT, Jones HG (2010) New phenotyping methods for screening wheat and barley for beneficial responses to water deficit. J Exp Bot. 61: 34993507.

Muñoz-Amatriaín M, Cuesta-Marcos A, Hayes PM, Muehlbauer GJ (2017) Barley genetic variation: implications for crop improvement. Brief Funct Genomics. 13: 341-350.

Monica S and Seetharaman N (2016) Effect of gamma irradiation and ethyl methane sulphonate (EMS) mutagenesis in early generation of garden bean (Lablab purpureus L.) sweet var. typicus). Inter J Adv Sci Tech Res. 6: 398-410.

Muñoz-Miranda LA, Rodríguez-Sahagún A, Hernández GJA, Cruz-Martínez, VO, Torres-Morán MI, Lépiz-Ildefonso R, Aarland RC, Castellanos-Hernández, OA (2019) Evaluation of somaclonal and ethyl methanesulfonate-induced genetic variation of Mexican oregano (Lippia graveolens H.B.K.). Agron. 9: 166-177.

Nice LM, Steffenson BJ, Blake TK, Horsley RD, Smith KP, Muehlbauer GJ (2017) Mapping agronomic traits in a wild barley advanced backcross-nested association mapping population. Crop Sci. 57:1199-1210.

Olaolorun BM, Shimelis, HA, Mathew I, Laing MD (2019) Optimising the dosage of ethyl methanesulphonate mutagenesis in selected wheat genotypes. S Afr J Plant Soil. 35: 357-366.

Pathirana $R$ (2011) Plant mutation breeding in agriculture. $C A B$ Rev. 6: 1-20.

Rafi S, Kamili AN, Ganai BA, Mir MY, and Parray JA (2016) Morpho-biochemical evaluation of EMS regenerated mutants of Bergenia ciliata (Haw.) Sternb. under in vitro conditions. J Nat Nat Sci. 1: 1-4.
Rasmusson DC, Phillips RL (1997) Plant breeding progress and genetic diversity from de novo variation and elevated epistasis. Crop Sci. 37:303-310.

Serrat X, Esteban R, Guibourt N, Moysset L, Nogués S (2014). EMS mutagenesis in mature seed-derived rice calli as a new method for rapidly obtaining TILLING mutant populations. Plant Methods. 10: 1-13.

Sharma RP, Swaminathan MS (1969) Radiation and radiomimetic substances. In: Mutation breeding FAD (DAE Sud.). Proceeding Symposium. pp. 70-78.

Shirani DA, Niroshani KAC, Gaminie AW, Abeysinghe PD (2016) Determination of optimum dosage of the mutagen ethyl methanesulphonate (EMS) for mass treatment of shoot tips of banana variety 'Agra'. Sri Lanka J Food Agric. 2: 1-9.

Sullivan P, Arendt E, Gallagher E (2013) The increasing use of barley and barley by-products in the production of healthier baked goods. Trends Food Sci Tech. 29: 124-134.

Talebi AB, Talebi AB, Shahrokhifar B (2012) Ethyl methanesulphonate (EMS) induced mutagenesis in Malaysian rice (cv. MR219) for lethal dose determination. Am J Plant Sci. 3: 1661-1665.

Van Harten AM (1998) Mutation breeding, theory and practical applications. Cambridge University Press, Cambridge, United Kingdom. 127-140 pp. 